\title{
Colonization of Wild Saccharomyces cerevisiae Strains in a New Winery
}

\author{
Hany Abdo ${ }^{1}$,, Claudia R. Catacchio ${ }^{2}$, Mario Ventura ${ }^{2}$, Pietro D'Addabbo ${ }^{2}$, \\ Francesco Maria Calabrese ${ }^{2}{ }^{1}$, Julie Laurent ${ }^{1}$, Vanessa David-Vaizant ${ }^{1}$, Hervé Alexandre ${ }^{1}$, \\ Michèle Guilloux-Bénatier ${ }^{1}$ and Sandrine Rousseaux ${ }^{1, *}$ \\ 1 Université Bourgogne Franche-Comté, AgroSup Dijon, PAM UMR A 02.102, F-21000 Dijon, \\ France-IUVV Equipe VAlMiS, rue Claude Ladrey, CEDEX BP 27877, 21078 Dijon, France; \\ hany.abdo@u-bourgogne.fr (H.A.); julie.laurent@u-bourgogne.fr (J.L.); \\ vanessa.david@u-bourgogne.fr (V.D.-V.); rvalex@u-bourgogne.fr (H.A.); mgb@u-bourgogne.fr (M.G.-B.) \\ 2 Department of Biology, University of Bari, 70125 Bari, Italy; claudiarita.catacchio@uniba.it (C.R.C.); \\ mario.ventura@uniba.it (M.V.); pietro.daddabo@uniba.it (P.D.A.); frankof.calabrese@gmail.com (F.M.C.) \\ * Correspondence: Sandrine.rousseaux@u-bourgogne.fr; Tel.: +33-380-396-261
}

Received: 19 November 2019; Accepted: 5 February 2020; Published: 12 February 2020

\begin{abstract}
The aim of this work was to study the fungal colonization of a new winery over time, specifically for Saccharomyces cerevisiae. Therefore, we analyzed the flora present before the arrival of the first harvest on the floor, the walls and the equipment of this new winery by Illumina MiSeq. The genus Saccharomyces $(\leq 0.3 \%)$ was detected on floor and equipment but the presence of $S$. cerevisiae species was not reported. Wild S. cerevisiae strains were isolated from a 'Pied de Cuve' used during the first vintage to ensure the alcoholic fermentation (AF). Among 25 isolates belonging to this species, 17 different strains were identified highlighting a great intraspecific diversity. S. cerevisiae strains were also isolated from different vats throughout the spontaneous fermentations during the first vintage. The following year, some of these strains were isolated again during AF. Some of them (four) were found in the winery equipment before the arrival of the third harvest suggesting a potential colonization by these strains. To better understand what promotes the yeast colonization of the winery's environment, the ability to form a biofilm on solid surfaces for eight colonizing or non-colonizing strains was studied. This capacity, different according to the strains, could partly explain the colonization observed for certain strains.
\end{abstract}

Keywords: new winery; Pied de Cuve; wine-related environment; Saccharomyces cerevisiae; biofilms

\section{Introduction}

In the winemaking process, several practices are used worldwide to ensure the alcoholic fermentation (AF). These practices include the use of commercial starters of active dry yeast (ADY), spontaneous fermentations and the method of 'Pied de Cuve'. The use of commercial starters of ADY has become one of the most common practices in winemaking worldwide [1,2]. In fact, this technique ensures (i) faster AF, (ii) production of desirable metabolites and (iii) reduction of the risk of wine spoilage [3-5]. For spontaneous fermentations, this practice relies on the natural fermentation of grape juice by the yeasts found on grape berries and winery environment. It has been demonstrated that the use of this practice positively impacts the sensory characteristics of wine and enhances its complexity due to the succession of multiple non-Saccharomyces and Saccharomyces species [6-10]. However, this uncontrolled biological process can result in a stuck or sluggish AF and increases the risk of wine spoilage due to the development of undesirable yeasts or bacteria [11,12]. To minimize the risks linked to spontaneous fermentations, winemakers can use a special method called 'Pied de Cuve' [13-16]. 
Depending on the winemaking techniques, the 'Pied de Cuve' can be prepared using indigenous yeast flora or commercial Saccharomyces cerevisiae strains. In the case of 'Pied de Cuve' prepared using indigenous yeast flora, grapes are collected, pressed and the must is fermented. Once at the beginning of AF, the 'Pied de Cuve' is inoculated into a new must. Thus, the 'Pied de Cuve' method applies viable yeast cells to start a new fermentation and promotes the growth of yeasts with good fermentation characteristics [16].

The majority of works has mainly studied the effect of the use of ADY S. cerevisiae strains on AF [17,18], but the implantation of ADY strains on wine-related environments (WREs) has also been highlighted $[19,20]$. Although no longer used, commercial starters of S. cerevisiae persist in winery ecosystem for one year and colonize new must even after two years [19]. As for ADY strains, during spontaneous AF the presence of wild strains on the WREs of wineries and their involvement during the AF of the same year was also described [20,21]. Plus, Grangeteau [22] demonstrated that some wild strains, originating from grape berries, are able to implement during the AF. However, the persistence of wild S. cerevisiae on WREs and their implantation during future fermentations has not been demonstrated yet. According to the literature, if implantation of wild yeasts brought by the 'Pied de Cuve' during spontaneous AF of the same year has been demonstrated [14], their persistence on the WREs is still not clearly established [13-16]. Nevertheless, all the above-mentioned works were carried out in wineries in production: dynamics, implantation and persistence of $S$. cerevisiae strains in a new winery are subjects that have not been extensively studied. To our knowledge, only three studies have been conducted in newly established wineries, but these new wineries used commercial yeasts [23-25]. Thus, no data are available concerning the involvement of spontaneous fermentations and/or the 'Pied de Cuve' method in the colonization and persistence of S. cerevisiae strains on WREs in a new winery.

The persistence of microorganisms under stressful environmental conditions such as winery environments can be due to multiple mechanisms. For example, the ability to kill or inhibit other microorganisms (yeast and/or bacteria) by the production of killer toxins is a strategy of persistence for S. cerevisiae in the environment [26,27]. Another potential strategy is the capacity of S. cerevisiae to enter in viable but non culturable (VBNC) state when environmental conditions become stressful [28]. Indeed, biofilm mode of life is described as strategy allowing microorganisms to better adapt to environmental conditions [29-31]. The adhesion properties of commercial strains on winery hose have been demonstrated and can contribute to the persistence of these yeasts in winery environment and to their potential implantation in uninoculated fermentations [32].

Based on this context, wine related environments (WREs) can be considered as an important ecological niche for yeast flora that can also be implicated during winemaking. Thus, this study aimed to understand how a new winery can be colonized by yeasts with several objectives: (i) identify wild Saccharomyces cerevisiae strains present in the environment of a new winery (floor, walls and equipment) before the arrival of the first harvest, (ii) highlight the colonization of the winery's environments by strains of Saccharomyces cerevisiae isolated in the PDC made in the first year or isolated from the musts and wines of two consecutive vintages, (iii) compare the ability to form biofilms between "colonizing" strains and punctually present strains.

\section{Material and Methods}

\subsection{Sampling of Winery Related Environments (WREs)}

Samples were taken during three consecutive vintages (2016, 2017 and 2018) in a new winery located in Nuits-Saint-Georges (Bourgogne, France). The samples were collected from three different winery environments (WREs): floor (F), walls (W), equipment (E). Two sampling times were selected: before the receipt of grapes in the winery (T0) and three months after the end of the fermentations (T3) to observe if yeast strains have been able to implant or colonize the WREs while the activity of the winery is low. For the 2016 vintage, at T0 time point, the majority of the equipment in the new winery was new, except for certain vats $(36 / 108)$ that have already been used before. The equipment 
sampled included lift conveyor belts, destemmers, presses, stainless steel vats, wooden vats, pumps, and transfer pipes. For the 2017 vintage, the same sampling methodology was followed with two sampling times T0 and T3. The sampling was carried out for two full years (from T0 2016 to T0 2018), so sampling for the vintage 2018 was realized before the arrival of the harvest (T02018), All the samples were collected by streaking specific areas of each WRE using sterile cotton swabs, which were then placed in an equivalent volume $(40 \mathrm{~mL}$ for 40 samples) of physiological water solution $(\mathrm{NaCl}$ at $0.9 \% w / v)$.

Given the significant number of samples realized by vintage at each sampling time, the samples were pooled to obtain average samples (per environment and for each sampling time point). For example, for the 2016 vintage, the 40 samples from the floor at T0 were pooled to form an average sample. Thus, a total of 7 average samples for 2016 vintage (floor, walls, new equipment, used equipment at T0, floor, walls, equipment at T3), 6 average samples for 2017 vintage (floor, walls, equipment at T0 and at T3) and 3 average samples for 2018 vintage (floor, walls, equipment at T0) were analyzed afterwards.

\section{2. "Pied de Cuve" (PDC)}

To ensure the spontaneous fermentations in the new winery, a PDC for 2016 was prepared by allowing $800 \mathrm{Kg}$ of Pinot Noir must to ferment spontaneously. To study the PDC's biodiversity: samples were collected at three different time points: before $\mathrm{SO}_{2}$ addition, $36 \mathrm{~h}$ after $\mathrm{SO}_{2}$ addition $(3 \mathrm{~g} / \mathrm{hL})$ and 7.5 days after $\mathrm{SO}_{2}$ addition $(\mathrm{d}=1.09)$. The PDC served for the inoculation of one fermentation vat (vat A) containing $31 \mathrm{hL}$ of must from the same appellation (Table 1).

Table 1. Name and must appellation of each fermentation vats followed throughout the 2016 and 2017 vintages.

\begin{tabular}{ccc}
\hline \multicolumn{2}{c}{ Name of Fermentation Vat } & Must Appellation \\
\cline { 1 - 2 } $\mathbf{2 0 1 6}$ Vintage & 2017 Vintage & \multirow{2}{*}{ Beaune 1er Cru-Clos de l'Ecu } \\
\cline { 1 - 2 } Pied de Cuve & - & \\
\hline A & A & Volnay 1er Cru-Fremiets \\
\hline B & B and B' & Monthélie 1er Cru-Champs Fulliot \\
\hline C & &
\end{tabular}

\subsection{Must/Wine Samples}

The first vinification took place in the new winery during the 2016 vintage. Must and wine samples were collected from three different fermentation vats (A, B and C) containing musts from different appellations (Table 1). Samples were collected in fresh musts and before inoculation by PDC in the vat $\mathrm{A}(\mathrm{T} 0)$ and at end of fermentation $(\mathrm{E}-\mathrm{AF})$ when the density kept constant $(\approx 0.99)$. Must and wine samples were collected and shipped on ice to the lab for plating and further analysis.

The same sampling methodology was followed during the 2017 vintage but no PDC were set-up to initiate the alcoholic fermentation during this year. Four different fermentation vats $\left(\mathrm{A}, \mathrm{B}, \mathrm{B}^{\prime}\right.$ and $\left.\mathrm{C}\right)$ were followed-up during the second vintage. The vats $A, B, B^{\prime}$ and $C$ contained must from the same appellations as the 2016 vintage (Table 1). Two sampling time points were considered: fresh must (T0) and end of the fermentation (E-AF).

\subsection{Illumina Sequencing}

\subsubsection{DNA Extraction}

A total of $10 \mathrm{~mL}$ of each average sample was centrifuged at $4000 \mathrm{rpm}$ for $4 \mathrm{~min}$ at $4{ }^{\circ} \mathrm{C}$. The supernatant was discarded, and the cell pellet was suspended in $200 \mu \mathrm{L}$ of DNA-Yeast extraction buffer (2\% Triton X-100 (v/v), 1\% SDS $(w / v), 100 \mathrm{mM} \mathrm{NaCl}, 10 \mathrm{mM}$ Tris and $1 \mathrm{mM}$ EDTA at $\mathrm{pH}$ 8). Then, 
$60 \mu \mathrm{L}$ of phenol/chloroform/isoamyl alcohol (25:24:1) and $0.3 \mathrm{~g}$ of glass beads ( $0.5 \mathrm{~mm}$ in diameter; Scientific Industries, Bohemia, NY, USA) were added. The cells were lysed by Precellys 24-Dual (Bertin Technologies, Montigny le Bretonneaux, France) for $3 \times 45 \mathrm{~s}$ and placed on ice for $2 \mathrm{~min}$. Afterwards, $200 \mu \mathrm{L}$ of TE Buffer was added (10 mM Tris and $1 \mathrm{mM}$ EDTA pH 8$)$ and the mixture was centrifuged at $13700 \mathrm{rpm}$ for $10 \mathrm{~min}$ at $4{ }^{\circ} \mathrm{C}$. The supernatant was collected and the DNA was precipitated with $1 \mathrm{~mL}$ of $100 \%(v / v)$ ethanol solution and centrifuged at $13700 \mathrm{rpm}$ for $10 \mathrm{~min}$ at 20 ${ }^{\circ} \mathrm{C}$. The DNA pellet was washed with $70 \%(v / v)$ ethanol solution and centrifuged at $13700 \mathrm{rpm}$ for 5 min at $20^{\circ} \mathrm{C}$. Finally, the DNA pellet was dried at $95^{\circ} \mathrm{C}$ for $5 \mathrm{~min}$ to remove the excess ethanol and re-suspended in $40 \mu \mathrm{L}$ of Milli-Q water and stored at $-20^{\circ} \mathrm{C}$.

For must/wine samples, a filtration step was carried out prior to DNA extraction using a polyamide column (2.5 g of MN Polyamid SC6 Macherey-Nagel, Düren, Germany). The column was rinsed with $\mathrm{NaCl} 1 \mathrm{M}$ solution and then $10 \mathrm{~mL}$ of each must/wine sample were collected and filtered through it. The filtered suspension was centrifuged at $13,700 \mathrm{rpm}$ for 4 min at $4{ }^{\circ} \mathrm{C}$.

\subsubsection{ITS Amplicon Library Preparation}

The nuclear ribosomal internal transcribed spacer 2 (ITS2) region of the fungal DNA was amplified for this analysis in a one-step amplification protocol using a mono index approach. The fusion primers selected for this study were the 5.8S-Fun (5'-CAAGCAGAAGACGGCATAC GAGAT-NNNNNNNNNNNN-AGTCAGTCAG-GG-AACTTTYRRCAAYGGATCWCT-3') and the ITS4-Fun (5'-AATGATACGGCGACCACCGAGATCTACAC-TATGGTAATT-AA-AGCCTCCGCTTAT TGATATGCTTAART-3') (core PCR primer in bold). The fusion primers contained the 24-to 29-bp Illumina sequencing adaptor, the 12-bp Golay barcode (5.8S-Fun exclusively), a 10-bp primer pad, a 2-bp linker, and the 21-to 27-bp core primer. The different elements are separated by dashes, and Golay barcodes are shown as Ns [33].

PCR amplification was carried out in a final volume of $50 \mu \mathrm{L}$, including $2 \mu \mathrm{L}$ DNA template, $0.3 \mu \mathrm{L}$ of Platinum Taq DNA Polymerase $2.5 \mathrm{U}$ (Invitrogen ${ }^{\mathrm{TM}}$, Waltham, MA, USA), $1 \times$ Taq buffer, $20 \mu \mathrm{M}$ dNTP and $1 \mu \mathrm{L}$ of each primer $10 \mu \mathrm{M}$. The PCR program consisted in denaturing for $5 \mathrm{~min}$ at $94{ }^{\circ} \mathrm{C}$, followed by 30 cycles of $30 \mathrm{~s}$ at $94{ }^{\circ} \mathrm{C}, 1 \mathrm{~min}$ at $60^{\circ} \mathrm{C}, 1 \mathrm{~min}$ at $72{ }^{\circ} \mathrm{C}$ and final extension at $72{ }^{\circ} \mathrm{C}$ for $5 \mathrm{~min}$. Finally, the pooled PCR products were size-selected with an Invitrogen ${ }^{\circledR} 2 \% \mathrm{E}-\mathrm{Gel}$, purified using the QIAquick purification kit (Qiagen, Germantown, MD, USA). Their concentration was determined with the Qubit ${ }^{\circledR}$ dsDNA HS Assay Kit (Thermo Fisher Scientifics, Waltham, MA, USA). The pooled PCR products were sequenced with an Illumina ${ }^{\circledR}$ MiSeq sequencer $(2 \times 300$ cycles $)$ following manufacturer's instructions (Illumina, San Diego, CA, USA). Final libraries were diluted to 4-6 pM before loading and 20-25\% PhiX control DNA was spiked in the run to add base diversity.

\subsubsection{Sequence Analysis}

Data from MiSeq sequencing were analyzed with PIPITS, an automated pipeline for the detection and differentiation of fungal internal transcribed spacer (ITS) [34]. Raw data were demultiplexed and barcodes and primers were trimmed off. Quality filters were applied, using a FASTX Toolkit. High-quality reads were clustered into operational taxonomic units (OTUs) at $97 \%$ similarity using VSEARCH and chimaeras excluded using also VSEARCH [35]. Taxonomy was assigned with RDP Classifier [36] against the UNITE fungal ITS reference dataset [37]. Finally, relative abundances of fungal taxa in each sample were calculated and compared. The results have been published in a public database (accession code: bioproject_accession PRJNA603502).

\subsection{Yeast Isolation}

Colony counting on plates were carried out for each average samples taken from PDC, must, wine and winery surfaces according to the protocol described by Grangeteau et al. [38]. After incubation, up to 50 yeast colonies were randomly selected and isolated at each sampling time point from plates 
containing between 30-300 colonies. The isolates obtained throughout this work were stored in glycerol $(25 \%, v / v)$ at $-80^{\circ} \mathrm{C}$ for later identification.

\subsection{Molecular Identification of Yeast Isolates}

\subsubsection{ITS-PCR}

DNA extraction was realized from fresh colonies as previously described by Werner et al. [39]. Briefly, one colony was mixed with $40 \mu \mathrm{L}$ of $\mathrm{NaOH}$ solution $(20 \mathrm{mM})$ and heated for $10 \mathrm{~min}$ at $95^{\circ} \mathrm{C}$. After centrifugation at $4000 \mathrm{rpm}$ for $10 \mathrm{~min}$, the pellet was discarded and the supernatant containing the DNA was preserved for PCR analysis.

Internal transcribed spacer (ITS) 5.8S rDNA region was amplified using the primers ITS1 and ITS4 for differentiation between Saccharomyces and non-Saccharomyces isolates [40]. PCR conditions were followed as previously described by Esteve-Zarzoso et al. [41]. PCR products were separated by microchip electrophoresis (MultiNA MCE202, Shimadzu, Tokyo, Japan).

\subsubsection{Interdelta PCR Typing}

Intra-specific diversity among the $S$. cerevisiae isolates was studied by interdelta analysis. Primers $\delta 12$ and $\delta 21$ were used and the PCR reaction was performed as previously described by Legras and Karst [42]. Interdelta profiles were analyzed and visualized by microchip electrophoresis (MultiNA MCE202, Shimadzu, Tokyo, Japan).

\subsection{Biofilm Formation of S. cerevisiae}

Biofilm formation was monitored for 8 selected strains of S. cerevisiae isolated during this study. In addition, one commercial strain of $S$. cerevisiae (Lalvin Rhône 2056), known for its capacity to form biofilms, was added to this study as a positive control [32,43].

From $-80^{\circ} \mathrm{C}$ stored cultures, starter cultures of $S$. cerevisiae were prepared in triplicates into $1.5 \mathrm{~mL}$ of YPD medium at $28^{\circ} \mathrm{C}$ during $24 \mathrm{~h}$. Then, the starter cultures were passed twice into fresh medium to obtain cultures in the same physiological state. Then, cell suspensions were readjusted at $\mathrm{OD}_{600 \mathrm{~nm}}=0.05\left(1 \mathrm{OD}_{600 \mathrm{~nm}}=1.0 \times 10^{7} \mathrm{CFU} / \mathrm{mL}\right)$ in YPD medium to obtain the "YPD working culture".

Biofilm formation was studied on stainless steel chips using a protocol previously described by Bastard et al. [31] and adapted to the yeast S. cerevisiae. Stainless-steel chips $(25 \mathrm{~mm} \times 25 \mathrm{~mm}$, Goodfellow, 316L, France) were immersed in $13 \mathrm{~mL}$ of "YPD working culture" adjusted at $1.2 \times 10^{5} \mathrm{CFU} / \mathrm{mL}$ and incubated for 2,24 and $48 \mathrm{~h}$ at $28^{\circ} \mathrm{C}$. After incubation, chips were collected and rinsed twice $30 \mathrm{~s}$ in $15 \mathrm{~mL}$ of sterile physiological water to eliminate non-adhered cells on chips. Afterwards, chips were placed in a new sterile physiological water $(15 \mathrm{~mL})$ and cells were detached by sonication (Bransonic CPXH1800H-E; Branson Ultrasonic Corporation, Danbury, CT, USA) for 3 min. The detached cells from chips and contained in the cell suspension were numbered by plating on YPD plates at $28^{\circ} \mathrm{C}$ after serial dilutions. This experiment was also realized in three independent biological repetitions for each strain.

\subsubsection{Scanning Electron Microscopy (SEM)}

The $48 \mathrm{~h}$-aged biofilms were formed on stainless steel chips. Cells were directly fixed on stainless steel by a solution of $3 \%$ glutaraldehyde in $0.1 \mathrm{M}$ phosphate buffer $\mathrm{pH} 7.2$ for $3 \mathrm{~h}$ at $4{ }^{\circ} \mathrm{C}$. The samples were then washed with $0.05 \mathrm{mM}$ phosphate buffer for $10 \mathrm{~min}$ at room temperature. Dehydration was performed by two successive immersions for $10 \mathrm{~min}$ in solutions of increasing ethanol content $(30,50,70,90,100 \%)$. Then, multiple baths of ethanol-acetone solution $(70: 30,50: 50,30: 70,100 \%)$ were realized during $10 \mathrm{~min}$ for each mixture. Then, the chips were air-dried and stored at room temperature. Afterward, the samples were coated with a thing gold layer using an Edwards Scancoat Six Pirani 201 sputter coater (Edwars High Vacuum, Crawley, England) and then observed with a 
Hitachi SU1510 scanning electron microscope (Hitachi High-Technologies Corporation, Tokyo, Japan). SEM was performed at an accelerating voltage of $15 \mathrm{kV}$ using at a working distance between $7.5 \mathrm{~mm}$.

\subsubsection{Statistical Analysis}

All biofilm assays were performed in three biological replicates. A one -way analysis of variance (ANOVA) with a post -hoc Tukey honestly significant difference (HSD) test was used for statistical comparison. A $p$-value $\leq 0.05$ was considered statistically significant.

\section{Results and Discussion}

\subsection{Saccharomyces Status in the New Winery before the Arrival of the First Harvest}

The status of the Saccharomyces genus in a new winery was studied in order to provide new knowledge on the presence of this genus on the WREs of a new winery, which has never been studied before. Thus, samples from three different WREs (floor, walls and equipment) were collected before the arrival of the first harvest and analyzed by Illumina MiSeq. The genus Saccharomyces was only detected on winery floor and used equipment at very low percentages $(\leq 0.3 \%)$ compared to the higher percentage of non-Saccharomyces yeast genera (24 genera) detected on the three WREs (Table 2). The presence of genus Saccharomyces on the equipment is not surprising considering that certain vats (36/108) had already been used before. So, the presence of the genus Saccharomyces can be linked to must and/or wine residues found particularly in areas that are difficult to clean. The detection of this genus on the winery floor could be explained by the potential transfer between used equipment and winery floor due to human activities. This result confirms that genus Saccharomyces is a genus related to fermentation activity and not a ubiquitous genus of the winery environment [44-46].

Table 2. Percentages of non-Saccharomyces and Saccharomyces genera identified on wine-related environments (WREs) before the arrival of the first harvest by Illumina sequencing.

\begin{tabular}{|c|c|c|c|}
\hline \multirow{2}{*}{ Yeast Genus } & \multicolumn{3}{|c|}{ T0 2016} \\
\hline & Floor & Walls & Equipment \\
\hline Non-Saccharomyces * & 99.7 & 100.0 & 99.9 \\
\hline Saccharomyces & 0.3 & 0.0 & 0.1 \\
\hline
\end{tabular}

* Identified non-Saccharomyces genera: Aureobasidium, Barnettozyma, Bullera, Candida, Curvibasidium, Cryptococcus, Cystobasidium, Debaryomyces, Filobasidium, Hanseniaspora, Holtermanniella, Metschnikowia, Meyerozyma, Nakazawaea, Pichia, Rhodosporidiobolus, Rhodotorula, Saccharomycodes, Sporobolomyces, Solicoccozyma, Torula, Trigonopsis, Vishniacozyma and Wickerhamomyces.

Despite the low representation of the genus Saccharomyces, we investigated whether these consisted of the species Saccharomyces cerevisiae by identification of the isolates by PCR-ITS. None of the isolates analyzed belonged to this species, probably too minor to be detected by the strategy employed. Moreover, detection of this genus by Illumina MiSeq can be linked to the sequencing of DNA from dead cells or cells in viable but non-culturable (VBNC) state, previously demonstrated for S. cerevisiae [28].

\subsection{Yeast Biodiversity in 'Pied de Cuve' (PDC)}

A 'Pied de Cuve' was prepared and samples were collected at three different time points (before $\mathrm{SO}_{2}$ addition, $36 \mathrm{~h}$ after $\mathrm{SO}_{2}$ addition and 7.5 days after $\mathrm{SO}_{2}$ addition) and analyzed by Illumina MiSeq.

Before $\mathrm{SO}_{2}$ addition, 21 yeast genera were identified and the genus Hanseniaspora was the most dominant by more than $90 \%$ of the total abundance (Figure 1A). The dominance of this genus was described previously on grapes and in must $[47,48]$. Other genera of enological interest like Candida, Metschnikowia and Pichia were also detected and are usually isolated on grapes and in fresh must [48]. Nevertheless, the genus Saccharomyces was not detected before $\mathrm{SO}_{2}$ addition probably due to the low occurrence of this genus on grape berries $[49,50]$. 


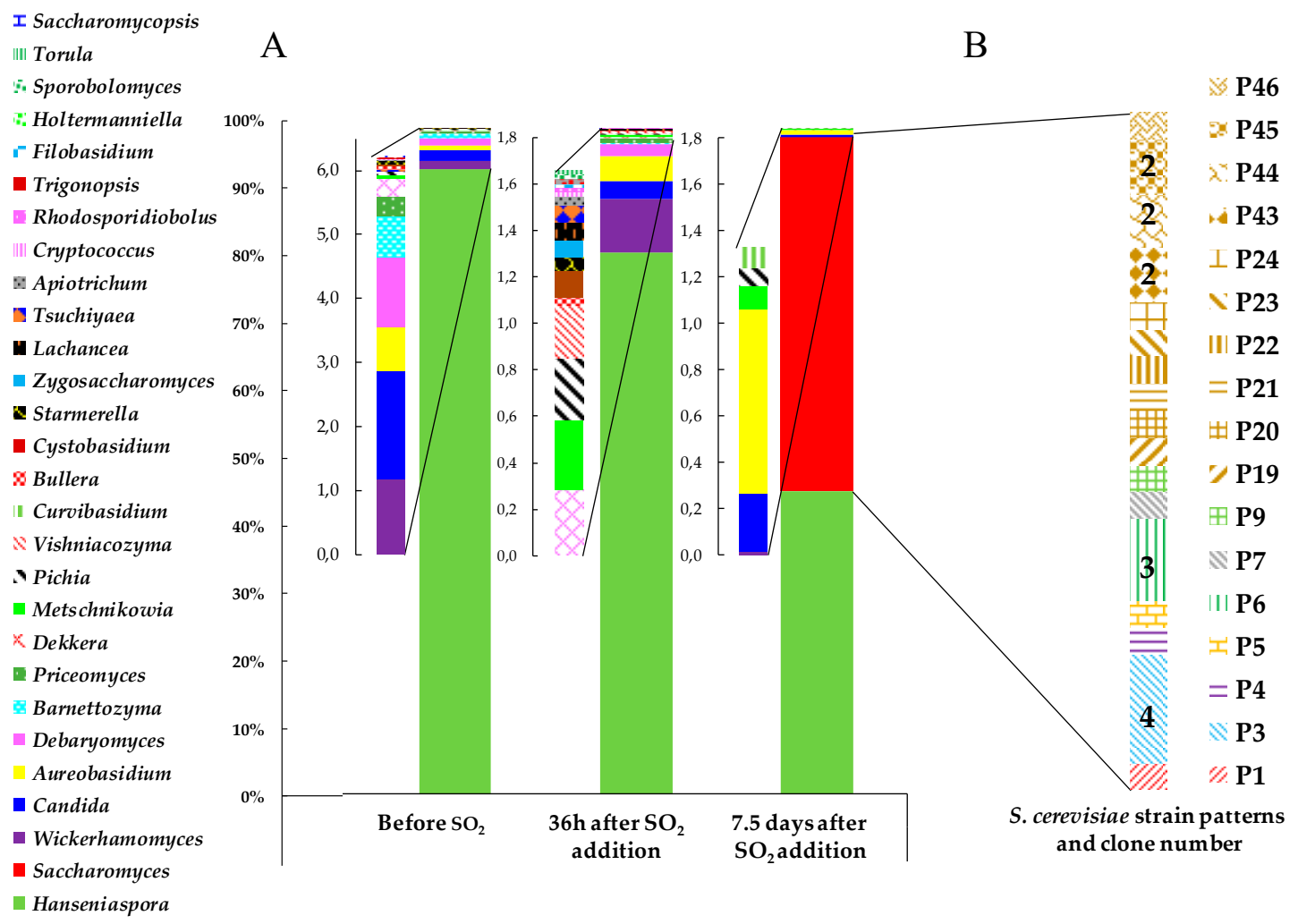

Figure 1. (A) Relative abundance of fungal genera identified in 'Pied de Cuve' for vintage 2016. (B) Number of isolates for S. cerevisiae strains in 'Pied de Cuve' at 7.5 days after $\mathrm{SO}_{2}$ addition. Only the number of isolates per strain $\geq 2$ is noted.

At $36 \mathrm{~h}$ after $\mathrm{SO}_{2}$ addition, 24 yeast genera were identified and a slight decrease in the abundance of the genus Hanseniaspora was observed. The genera Apiotrichum, Cryptococcus, Filobasidium, Holtermanniella, Lachancea, Rhodosporidiobolus, Sporobolomyces, Torula, Trigonopsis and Tsuchiyaea were newly detected. As well, an increase in the abundance of the genera Aureobasidium, Candida and Wickerhamomyces already detected before $\mathrm{SO}_{2}$ addition was observed. Tolerance to high concentration of sulfur dioxide was previously demonstrated for the genera Candida and Wickerhamomyces [51,52]. Despite its better resistance to sulfur dioxide [53], the genus Saccharomyces was still not detected, as previously observed by Moschetti et al. [16].

At 7.5 days after $\mathrm{SO}_{2}$ addition, eight yeast genera were identified. Among them, the genus Saccharomyces was detected at $53 \%$ of the total abundance due to the beginning of the AF. The majority of the non-Saccharomyces genera previously found were no longer detected at 7.5 days after $\mathrm{SO}_{2}$ addition, except for the genera Hanseniaspora (45\%) and the genera Aureobasidium, Candida, Curvibasidium, Pichia, Metschnikowia and Wickerhamomyces that were also detected but with a low abundance (1.5\%).

At 7.5 days after $\mathrm{SO}_{2}$ addition, start of the $\mathrm{AF}$, yeast isolation on YPD agar medium was realized and a total of 25 isolates belonging to the species S. cerevisiae were identified by PCR-ITS. Among these 25 isolates, 17 different strain patterns were identified by interdelta PCR typing, highlighting a great intraspecific diversity (Figure 1B). Few studies described the diversity of wild S. cerevisiae strains in PDC. In this study, the diversity obtained is, as expected, higher than for a PDC made with commercial yeast [15] or for fortified PDC [16]. On the other hand, it corresponds to what is found in alcoholic fermentations made in native flora where the number of patterns is high $[47,54,55]$. 
3.3. Presence of Indigenous S. cerevisiae Detected in the PDC 2016 in the New Winery during 2016, 2017 and 2018

In order to study the presence of S. cerevisiae strains originated from the PDC 2016 in the new winery, samples were collected from WREs (2016, 2017 and 2018) and from different vats throughout the spontaneous fermentations during the first two vintages (2016 and 2017).

The two strains (P1and P3) found in the PDC were also isolated in the must of the vat A and in the two uninoculated vats B and C (Figure 2A). The strain P4 found in the PDC was also isolated in the must of the vat $\mathrm{A}$. We can say that these are strains associated with a given grape variety (Pinot noir) in a specific geographical location. At the end of AF 2016, the strain P1 is found in the wine of all vats (A, B and C) with a higher number of isolates. The strain P4 is found only in the wine of the vat A, the strain P3 in the wine of the vat B, and the strain P9 only in the wine of the vat $\mathrm{C}$. Presence of the strain $\mathrm{P} 9$ in the wine of the vat $\mathrm{C}$ but not in the must is probably due to a transfer from PDC by winery equipment (pumps, and transfer pipes) or by the air of the winery [56] (Figure 2A).

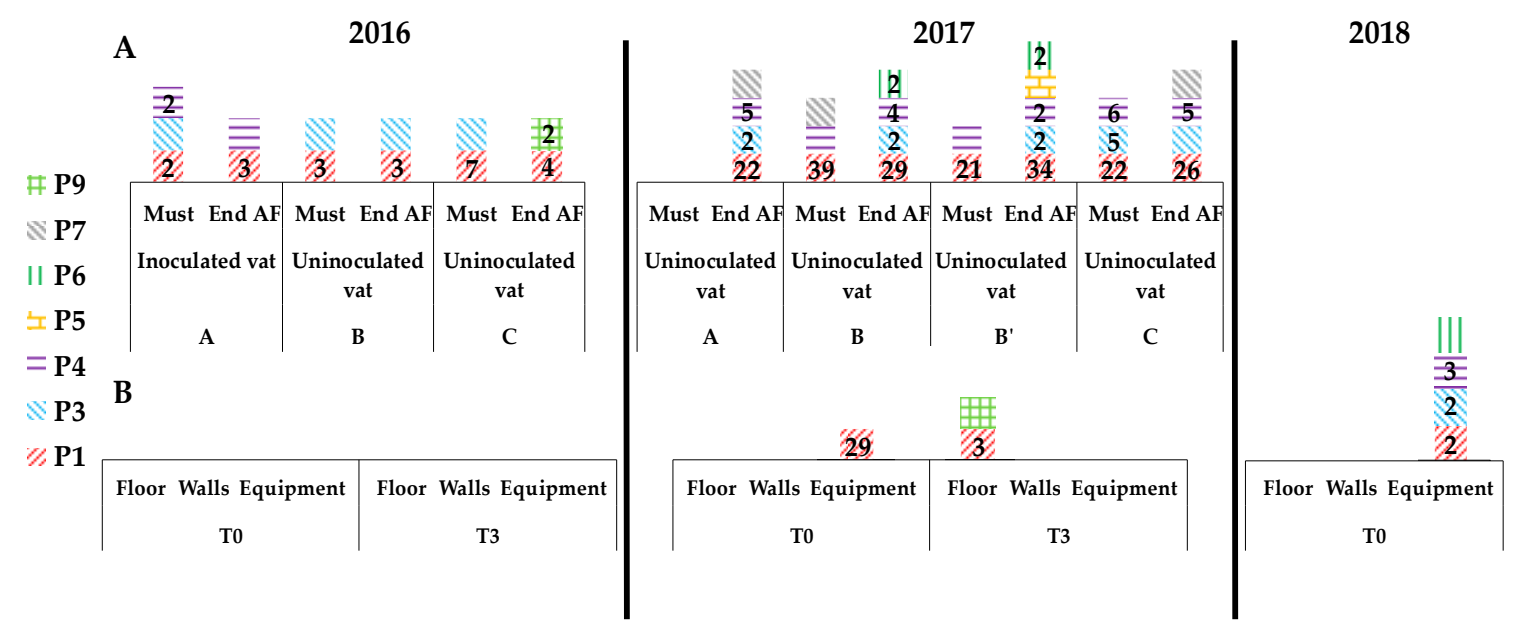

Figure 2. Persistence of strains of $S$. cerevisiae originated from Pied de Cuve (PDC) in the new winery studied during the three vintages: (A) In followed vats during the fermentations and (B) on WREs. Only the number of isolates per strain $\geq 2$ is noted.

However, three months after the AF (T3), no Saccharomyces cerevisiae strains from the PDC were detected on the WREs: walls, floor and equipment (Figure 2B). Thus, the environment appears very unfavorable to this yeast species and the yeast population is very low since we have not detected any yeast with the methodology used.

Before the arrival of the next harvest (T0 2017), strain P1 was detected on winery equipment with a high number of isolates (29) (Figure 2B). Then, this strain was detected with a large number of isolates in must for the vats $\mathrm{B}, \mathrm{B}^{\prime}$ and $\mathrm{C}$ (Figure 2A). Either this strain is transferred by the equipment into the vats $B, B^{\prime}$ and $C$, or it is a recurring strain of the vineyard since this strain had already been found in all grape musts in 2016. The strains P3 and P4, found in musts in 2016 are again found in musts in 2017 ( $\mathrm{P} 3$ in vat $\mathrm{C}$ and $\mathrm{P} 4$ in vats $\mathrm{B}, \mathrm{B}^{\prime}$ and $\mathrm{C}$ ). They also appear to be vineyard strains. No strain from PDC was detected in must vat $\mathrm{A}$ for the vintage 2017.

At the end of alcoholic fermentation, the strains P1, P3 and P4 were found in the wines from all vats (A, B, B' and C). If no PDC strain has been detected in must vat A, P1 P3 and P4 strains have been detected after $\mathrm{AF}$, probably due to by an air transfer of the strains from fermentation vats $\left(\mathrm{B}, \mathrm{B}^{\prime}\right.$ and $\left.\mathrm{C}\right)$ during alcoholic fermentations [45,57].

This strain P1, found at T0 in 2017 in equipment, is also found after the alcoholic fermentation on the floor in 2017 and in the winery equipment at T0 (before arrival of harvest) in 2018. Even if strain P1 was not detected on WREs after AF 2016, this strain could have started to colonize the winery between 2016 and 2018 vintages. The strains P3 and P4, involved in the alcoholic fermentation of 2016 and 2017, 
are also detected in the winery equipment at T0 in 2018. So, strains of $S$. cerevisiae are able to colonize the WREs of a new winery.

\subsection{Implication of Spontaneous Fermentations on S. cerevisiae Population Found on WREs}

A total of 36 different strains were detected during the fermentations of the 2016 and 2017 vintages. Only the strain AF2, detected during 2016 vintage (must of vat A and in wine of vat B) was found for the vintage 2017 in musts of vats $A, B$ et C and in wines of vats A, B, B' and C. This strain represented $2 \%$ of the total isolates in 2016 and then 17\% in 2017 (Figure 3A). However, it is difficult to conclude to a transfer of this strain because this strain was not detected on WREs between the vintages 2016 and 2017. AF2 was again detected on WREs (equipment) in 2018 (Figure 3B). It could be an early colonization of the environment.

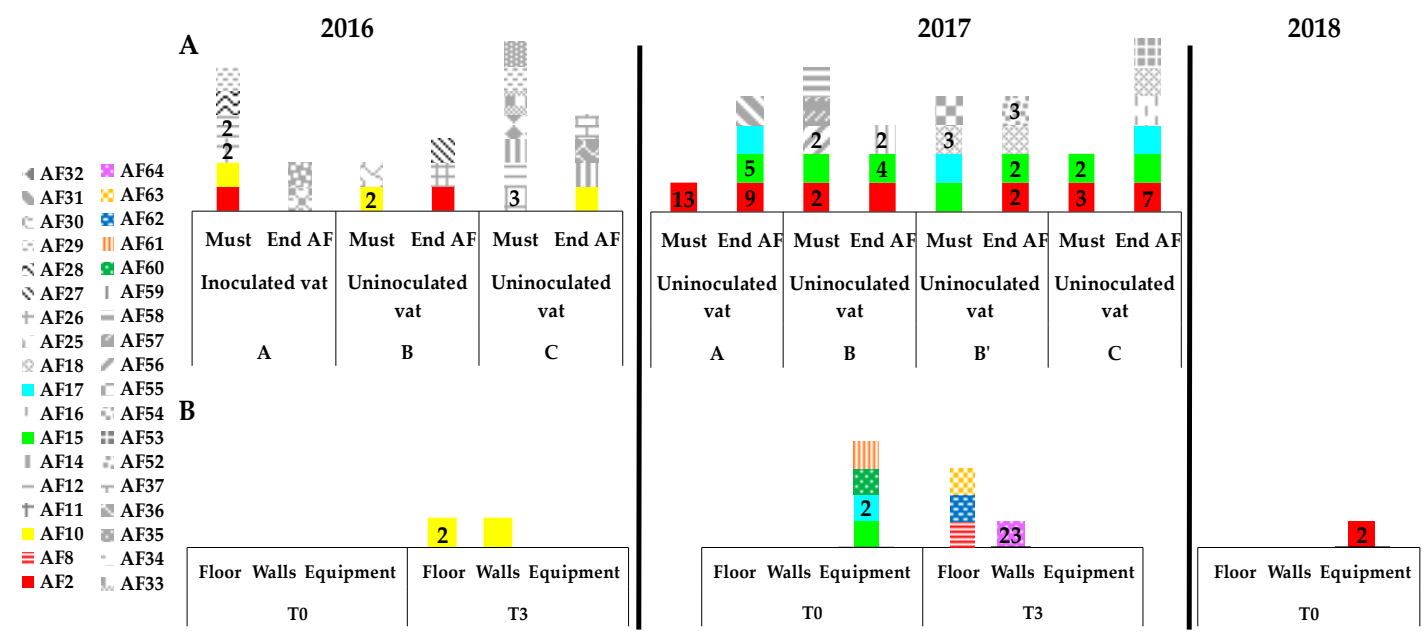

Figure 3. S. cerevisiae strains identified (A) in followed vats during the fermentation and (B) on winery surfaces during the three vintages. Only the number of isolates per strain $\geq 2$ is noted.

As previously described in literature [58,59], some strains seem specific to a vintage: for example, the strain AF10 was detected in all vats of the 2016 vintage and after AF on floor and walls (T3 2016), and the strains AF15 and AF17 were specific to 2017 vintage (Figure 3B). The presence of the strains AF15 and AF17on winery equipment at T0 2017, prior to the fermentation, is probably due to must handling before the sampling of the winery equipment. Three months after the end of fermentation 2017, four other strains (AF8, AF62, AF63 and AF64) were found on winery floor and walls, but were never detected during the fermentations of both years (Figure 3B). Their presence on WREs seems temporary because they were not detected in 2018.

Thus, the colonization of strains from spontaneous fermentations on WREs, which has never been reported before, is only slightly demonstrated in this work. Apparently only a very small number of strains appear able to be maintained in the environment of the winery between two vintages. It is also noteworthy to mention that, even by Illumina MiSeq, the detection of the genus Saccharomyces was between 0.1 and 1\% on WREs (data not shown). So, to better highlight the transfer of strains, the number of isolates should be considerably increased (not 50 isolates per sample but 500 or 1000).

\subsection{Capacity to form Biofilms on Stainless Steel}

To evaluate the ability of some strains to persist on WREs, eight strains were selected to study their capacity to form biofilms. The strains P1 and P4 found in particular in the PDC were selected according to their potential capacity to persist on WREs (for 2017 at T0 and T3 and for 2018 at T0). Strains AF8, AF28, AF63, AF64 and P19 isolated only one time in this study (on WREs at T3 2017 for AF8, AF63, AF64, in must 2016 for AF28 or in PDC 2016 for P19, respectively) were also selected. Strain AF10 was also selected because this strain was isolated only during vintage 2016 in must, wine and on 
WREs at T3. These six strains can be qualified as strains with low colonization capacity. In addition, one commercial strain (Lalvin Rhône 2056) was selected as reference strain whose biofilm capacity was previously described $[32,43]$. In total, nine strains were studied for their capacity to form biofilms on stainless steel.

Firstly, to confirm the capacity of the strains studied to form biofilms on stainless steel, SEM observations were realized on $48 \mathrm{~h}$ aged biofilms for two strains P1 and P19 (Figure 4). Microcolonies contained cells embedded in EPS matrix (exopolymeric substances) were observed for both strains and coherent with structures described for others species like Candida albicans, Hanseniaspora uvarum and Rhodotorula mucilaginosa [60-62]. Some differences were observed between both strains: the surface coverage for the strain P19 was more scattered and the microcolonies structures were less developed compared to the strain P1 (Figure 4).
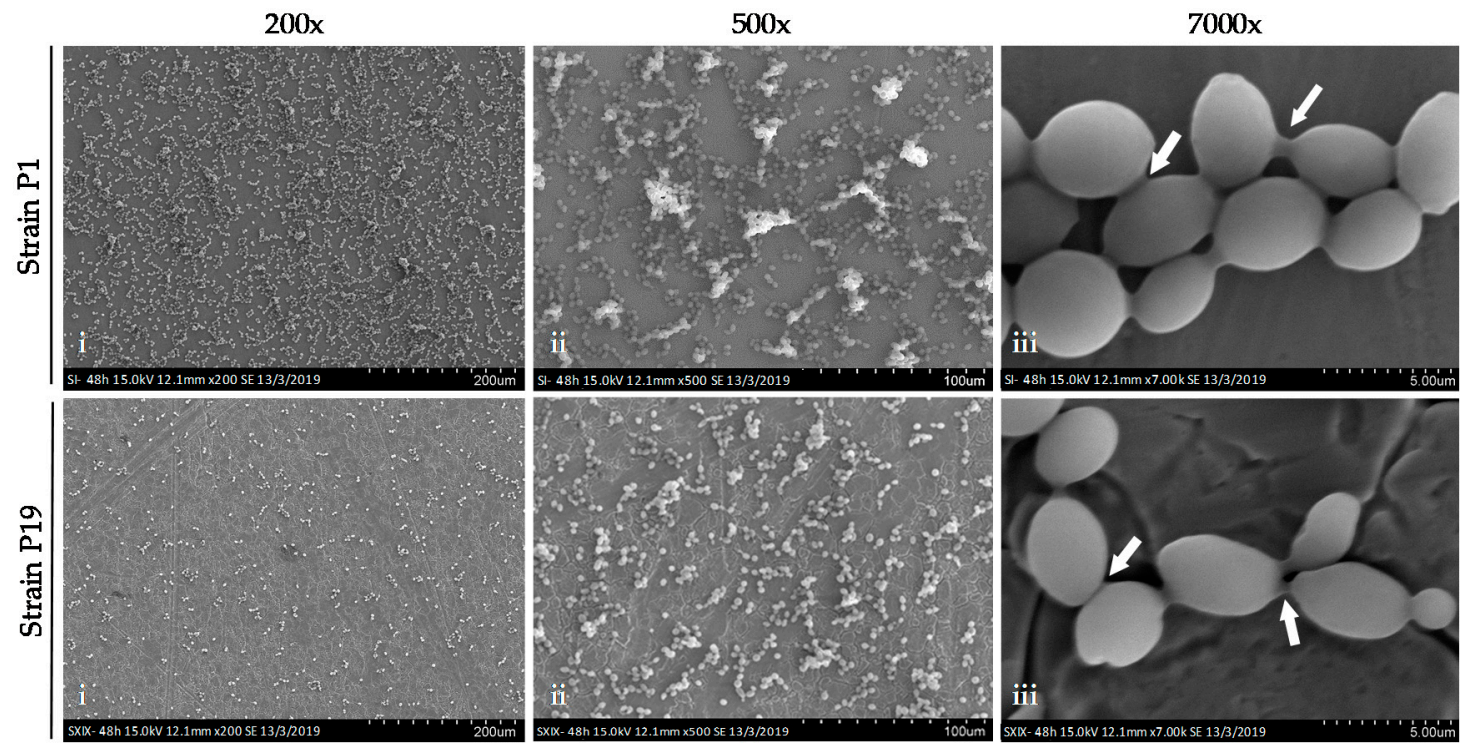

Figure 4. SEM observations of 48h-aged microcolonies for the strains P1 and P19 developed on stainless steel chips in YPD medium. (i) At 200x: adhered cells; (ii) at 500x: microcolonies and (iii) 7000x: microcolonies with exopolymeric substances (EPS—indicated by white arrows).

Secondly, adhesion ( $2 \mathrm{~h}$ ) and biofilm growth (48 h) were monitored for the nine selected strains on stainless steel chips (Figure 5). All strains were able to adhere on stainless steel after $2 \mathrm{~h}$ (average $4.2 \times 10^{4} \mathrm{CFU} / \mathrm{cm}^{2}$ ) and no significant difference was observed between strains (data not shown). But after 48 h, different growth of microcolonies was observed (Figure 5). For strains P1 and $\mathrm{P} 4$ selected for their potential capacity to colonize WREs, a growth was observed after $48 \mathrm{~h}$, particularly for the strain P1 (+1 Log CFU/cm²). Conversely, for strains AF10, AF63, AF64, AF28 and P19 selected for their low colonization capacity, no growth was observed after $48 \mathrm{~h}$. Moreover, the strain AF63 declined significantly. Only the strain AF8 showed significant growth after $48 \mathrm{~h}\left(+1 \mathrm{Log}\right.$ CFU/ $\left.\mathrm{cm}^{2}\right)$. Therefore, most strains isolated punctually or without potential persistence during two vintages in the new winery do not show microcolony growth on stainless steel. Using SEM observations, we validate the differences of strain behaviors. In fact, strain P19 characterized by a low potential persistence forms less microcolonies at $48 \mathrm{~h}$ than strain P1 described with a potential capacity for colonization (Figure 4).

Based on the different results obtained in this study we can suppose that the ability to form biofilms may be a factor favoring strain colonization or persistence. Kuthan et al. [63] have suggested that biofilms, surface adhesion and filamentous/invasive growth may confer, for wild $S$. cerevisiae strains, the ability to invade and thrive in unfavorable nutrient environments compared to domestic strains (laboratory strains) which lose this capacity because yeasts are grown routinely in rich media. 


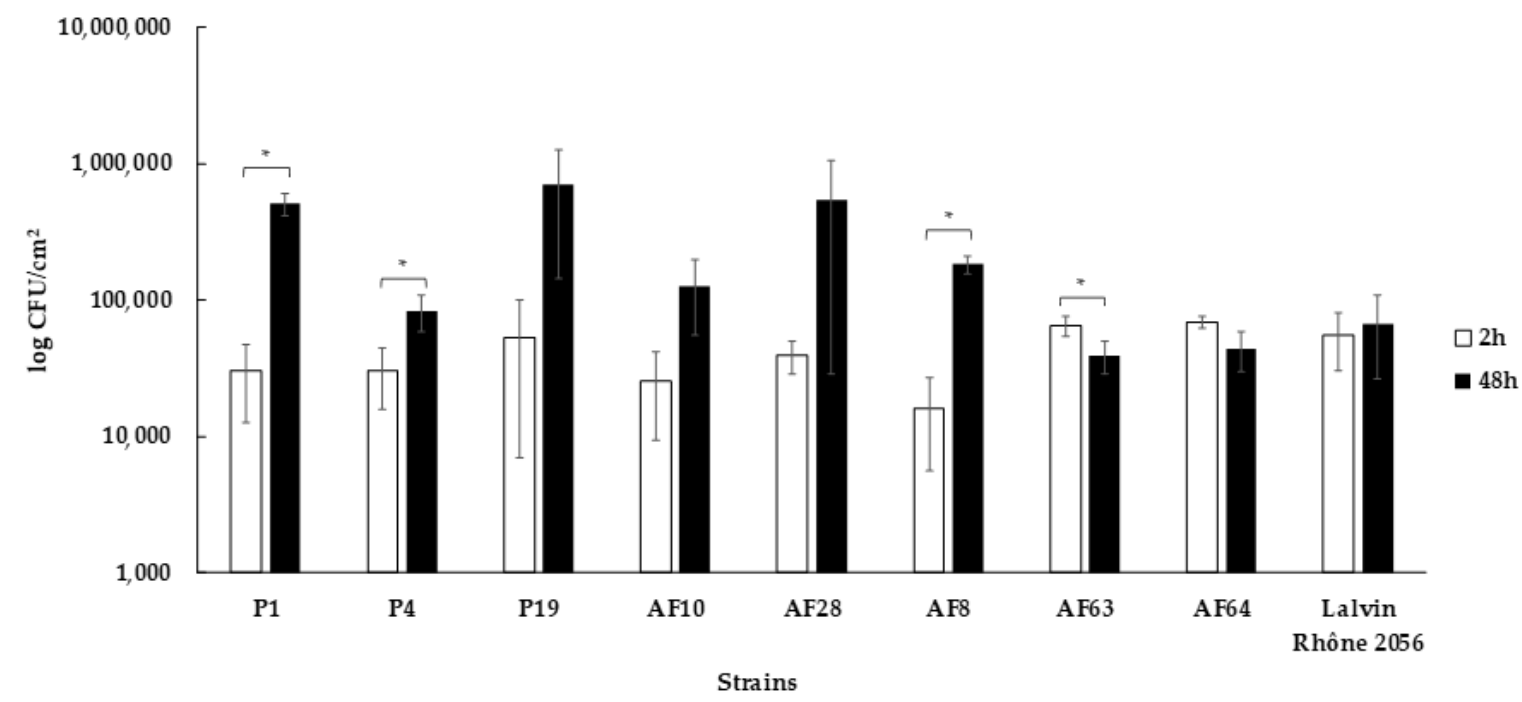

Figure 5. Microcolony growth on stainless steel chips in YPD medium for the selected strains $\left(\log \mathrm{CFU} / \mathrm{cm}^{2}\right)$. Errors bars represent the standard deviation between three independent biological replicates. Statistical analysis is performed between the two time points for each strain (ANOVA, $p$-value $\leq 0.05)$.

\section{Conclusions}

This study aimed to shed new light on the role of yeast flora found on wine related environments, and its involvement during winemaking. Therefore, this work provides first insights about the colonization of wild S. cerevisiae in a new winery operating only with indigenous flora. The isolation and identification of $S$. cerevisiae strains have been carried out in 'Pied de Cuve' (PDC), realized the first year, and during the spontaneous alcoholic fermentation in different vats. In total, 53 different strains were identified for the two consecutive vintages. Then, the search for these different strains has been carried out in wine-related environments like floor, walls and equipment (WREs) for the same vintages. Yeasts of the Saccharomyces cerevisiae species were scarcely detected in the WREs. Only some strains have been found in the WREs, thus showing a beginning of colonization of this environment. Among these, the P1 strain was found in 2016, 2017 and 2018 in grape musts and wines and in the WREs in 2017 and 2018 with a high number of isolates. This strain appeared both well adapted to the environment must and wine but also able to remain in the winery over time.

The ability to form a biofilm on stainless steel chips was studied for eight strains of Saccharomyces cerevisiae (colonizing strains and strains with a low colonization). Differences in biofilm structure and growth ability on stainless steel were observed between the studied strains and could partly explain the colonization observed for certain strains and in particular strain P1. This ability to colonize the environment could be strain-dependent like ethanol resistance and sulfite tolerance [64,65]. However, to support this hypothesis, further investigations will be needed. Moreover, the adhesion capacity should be studied for the different strains because it could also partly explain the colonization of the environments.

Author Contributions: Conceptualization S.R., M.G.-B., H.A. (Hany Abdo); data curation H.A (Hany Abdo); formal analysis H.A (Hany Abdo), C.R.C., M.V., P.D., F.M.C., J.L., V.D.-V.; investigation S.R., M.G.-B., H.A (Hany Abdo); methodology C.R.C., M.V., P.D., F.M.C.; resources C.R.C., M.V., P.D., F.M.C.; software C.R.C., M.V., P.D., F.M.C.; supervision S.R., M.G.-B., H.A. (Hervé Alexandre), M.V.; validation S.R., M.G.-B., H.A. (Hervé Alexandre); visualization S.R., M.G.-B., H.A. (Hervé Alexandre); writing—original draft. S.R., M.G.-B., H.A (Hany Abdo); writing-review and editing M.G.B. All authors have read and agreed to the published version of the manuscript.

Funding: This research was funded by the Regional Council of Bourgogne- Franche-Comté, the "Fonds Européen de Développement Régional (FEDER)" grant number [CRB 2016-9201AAO048S01632] and the "Bureau Interprofessionnel des Vins de Bourgogne (BIVB)" grant number [CONV1617_04]. 
Acknowledgments: The authors would like to thank the wine company who provided the facility in which this study was realized, Baptiste Pierre and Laurine Laroche for his technical help with the experiments and Marie-Laure Léonard and Jean-Marc Dachicourt (ESIREM, Université de Bourgogne, Dijon, France) for their technical assistance for the microscopic observations.

Conflicts of Interest: The authors declare no conflicts of interest.

\section{References}

1. Kraus, J.K.; Reed, G.; Villettaz, J.-C. Levures sèches actives de vinification. 1 $1^{\text {ère }}$ partie: Fabrication et caractéristiques. OENO One 1983, 17, 93-103. [CrossRef]

2. Reed, G.; Nagodawithana, T.W. Technology of yeast usage in winemaking. Am. J. Enol. Vitic. 1988, 39, 83-90.

3. Schuller, D.; Casal, M. The genetic structure of fermentative vineyard-associated Saccharomyces cerevisiae populations revealed by microsatellite analysis. Antonie Leeuwenhoek 2007, 91, 137-150. [CrossRef]

4. Belda, I.; Ruiz, J.; Esteban-Fernández, A.; Navascués, E.; Marquina, D.; Santos, A.; Moreno-Arribas, V. Microbial contribution to wine aroma and its intended use for wine quality improvement. Molecules 2017, 22, 189. [CrossRef]

5. Berbegal, C.; Spano, G.; Fragasso, M.; Grieco, F.; Russo, P.; Capozzi, V. Starter cultures as biocontrol strategy to prevent Brettanomyces bruxellensis proliferation in wine. Appl. Microbiol. Biotechnol. 2018, 102, 569-576. [CrossRef] [PubMed]

6. Fleet, G.H. Yeast interactions and wine flavour. Int. J. Food Microbiol. 2003, 86, 11-22. [CrossRef]

7. Fleet, G.H. Wine yeasts for the future. FEMS Yeast Res. 2008, 8, 979-995. [CrossRef] [PubMed]

8. Jolly, N.P.; Varela, C.; Pretorius, I.S. Not your ordinary yeast: Non-Saccharomyces yeasts in wine production uncovered. FEMS Yeast Res. 2014, 14, 215-237. [CrossRef]

9. Lu, Y.; Huang, D.; Lee, P.-R.; Liu, S.-Q. Assessment of volatile and non-volatile compounds in durian wines fermented with four commercial non-Saccharomyces yeasts. J. Sci. Food Agric. 2016, 96, 1511-1521. [CrossRef]

10. Petruzzi, L.; Capozzi, V.; Berbegal, C.; Corbo, M.R.; Bevilacqua, A.; Spano, G.; Sinigaglia, M. Microbial resources and enological significance: Opportunities and benefits. Front. Microbiol. 2017, 8, 995. [CrossRef]

11. Medina, K.; Boido, E.; Dellacassa, E.; Carrau, F. Growth of non-Saccharomyces yeasts affects nutrient availability for Saccharomyces cerevisiae during wine fermentation. Int. J. Food Microbiol. 2012, 157, 245-250. [CrossRef] [PubMed]

12. Jackson, R.S. Nature and origin of wine quality. In Wine Tasting: A Professional Handbook, 2nd ed.; Jackson, R.S., Ed.; Academic Press: Burlington, MA, USA, 2009; pp. 387-426.

13. Ubeda Iranzo, J.F.; González Magaña, F.; González Viñas, M.A. Evaluation of the formation of volatiles and sensory characteristics in the industrial production of white wines using different commercial strains of the genus Sacharomyces. Food Control 2000, 11, 143-147. [CrossRef]

14. Clavijo, A.; Calderón, I.L.; Paneque, P. Yeast assessment during alcoholic fermentation inoculated with a natural "pied de cuve" or a commercial yeast strain. World J. Microbiol. Biotechnol. 2011, 27, 1569-1577. [CrossRef]

15. Li, E.; Liu, C.; Liu, Y. Evaluation of yeast diversity during wine fermentations with direct inoculation and pied de cuve method at an industrial scale. J. Microbiol. Biotechnol. 2012, 22, 960-966. [CrossRef]

16. Moschetti, G.; Corona, O.; Gaglio, R.; Squadrito, M.; Parrinello, A.; Settanni, L.; Barone, E.; Francesca, N. Use of fortified pied de cuve as an innovative method to start spontaneous alcoholic fermentation for red winemaking. J. Grape Wine Res. 2016, 22, 36-45. [CrossRef]

17. Tello, J.; Cordero-Bueso, G.; Aporta, I.; Cabellos, J.M.; Arroyo, T. Genetic diversity in commercial wineries: Effects of the farming system and vinification management on wine yeasts. J. Appl. Microbiol. 2012, 112, 302-315. [CrossRef]

18. Martiniuk, J.T.; Pacheco, B.; Russell, G.; Tong, S.; Backstrom, I.; Measday, V. Impact of commercial strain use on Saccharomyces cerevisiae population structure and dynamics in Pinot Noir vineyards and spontaneous fermentations of a Canadian winery. PLoS ONE 2016, 11. [CrossRef]

19. Santamaría, P.; Garijo, P.; López, R.; Tenorio, C.; Gutiérrez, A.R. Analysis of yeast population during spontaneous alcoholic fermentation: Effect of the age of the cellar and the practice of inoculation. Int. J. Food Microbiol. 2005, 103, 49-56. [CrossRef] 
20. Mercado, L.; Dalcero, A.; Masuelli, R.; Combina, M. Diversity of Saccharomyces strains on grapes and winery surfaces: Analysis of their contribution to fermentative flora of Malbec wine from Mendoza (Argentina) during two consecutive years. Food Microbiol. 2007, 24, 403-412. [CrossRef]

21. Santamaría, P.; López, R.; López, E.; Garijo, P.; Gutierrez, A.R. Permanence of yeast inocula in the winery ecosystem and presence in spontaneous fermentations. Eur. Food Res. Technol. 2008, 227, 1563-1567. [CrossRef]

22. Grangeteau, C. Biodiversité Fongique du Raisin au Vin: Impact de l'activité anthropique. Ph.D. Thesis, Université de Bourgogne Franche-Comté, Dijon, France, 2016.

23. Constantí, M.; Poblet, M.; Arola, L.; Mas, A.; Guillamón, J.M. Analysis of yeast populations during alcoholic fermentation in a newly established winery. Am. J. Enol. Vitic. 1997, 48, 339-344.

24. Beltran, G.; Torija, M.J.; Novo, M.; Ferrer, N.; Poblet, M.; Guillamón, J.M.; Rozès, N.; Mas, A. Analysis of yeast populations during alcoholic fermentation: A six year follow- up study. Syst. Appl. Microbiol. 2002, 25, 287-293. [CrossRef] [PubMed]

25. Clavijo, A.; Calderón, I.L.; Paneque, P. Effect of the use of commercial Saccharomyces strains in a newly established winery in Ronda (Málaga, Spain). Antonie Leeuwenhoek 2011, 99, 727-731. [CrossRef] [PubMed]

26. Starmer, W.T.; Ganter, P.F.; Aberdeen, V.; Lachance, M.; Phaff, H.J. The ecological role of killer yeasts in natural communities of yeasts. Can. J. Microbiol. 1987, 33, 783-796. [CrossRef] [PubMed]

27. De Ullivarri, M.F.; Mendoza, L.M.; Raya, R.R. Killer activity of Saccharomyces cerevisiae strains: Partial characterization and strategies to improve the biocontrol efficacy in winemaking. Antonie Leeuwenhoek 2014, 106, 865-878. [CrossRef] [PubMed]

28. Salma, M.; Rousseaux, S.; Sequeira-Le Grand, A.; Divol, B.; Alexandre, H. Characterization of the viable but nonculturable (VBNC) state in Saccharomyces cerevisiae. PLoS ONE 2013, 8. [CrossRef]

29. Davey, M.E.; O’Toole, G.A. Microbial biofilms: From ecology to molecular genetics. Microbiol. Mol. Biol. Rev. 2000, 64, 847-867. [CrossRef]

30. O'Connell, H.A.; Kottkamp, G.S.; Eppelbaum, J.L.; Stubblefield, B.A.; Gilbert, S.E.; Gilbert, E.S. Influences of biofilm structure and antibiotic resistance mechanisms on indirect pathogenicity in a model polymicrobial biofilm. Appl. Environ. Microbiol. 2006, 72, 5013-5019. [CrossRef]

31. Bastard, A.; Coelho, C.; Briandet, R.; Canette, A.; Gougeon, R.; Alexandre, H.; Guzzo, J.; Weidmann, S. Effect of biofilm formation by Oenococcus oeni on malolactic fermentation and the release of aromatic compounds in wine. Front. Microbiol. 2016, 7, 613. [CrossRef]

32. Tek, E.L.; Sundstrom, J.F.; Gardner, J.M.; Oliver, S.G.; Jiranek, V. Evaluation of the ability of commercial wine yeasts to form biofilms (mats) and adhere to plastic: Implications for the microbiota of the winery environment. FEMS Microbiol. Ecol. 2018, 94. [CrossRef]

33. Taylor, D.L.; Walters, W.A.; Lennon, N.J.; Bochicchio, J.; Krohn, A.; Caporaso, G.J.; Pennanen, T. Accurate estimation of fungal diversity and abundance through improved lineage-specific primers optimized for Illumina Amplicon Sequencing. Appl. Environ. Microbiol. 2016, 82, 7217-7226. [CrossRef] [PubMed]

34. Gweon, H.S.; Oliver, A.; Taylor, J.; Booth, T.; Gibbs, M.; Read, D.S.; Griffiths, R.I.; Schonrogge, K. PIPITS: An automated pipeline for analyses of fungal internal transcribed spacer sequences from the Illumina sequencing platform. Methods Ecol. Evol. 2015, 6, 973-980. [CrossRef] [PubMed]

35. Rognes, T.; Flouri, T.; Nichols, B.; Quince, C.; Mahé, F. VSEARCH: A versatile open source tool for metagenomics. Peer] 2016, 4, E2584. [CrossRef] [PubMed]

36. Wang, Q.; Garrity, G.M.; Tiedje, J.M.; Cole, J.R. Naïve Bayesian classifier for rapid assignment of rRNA sequences into the new bacterial taxonomy. Appl. Environ. Microbiol. 2007, 73, 5261-5267. [CrossRef]

37. Kõljalg, U.; Larsson, K.H.; Abarenkov, K.; Nilsson, R.H.; Alexander, I.J.; Eberhardt, U.; Erland, S.; Høiland, K.; Kjøller, R.; Larsson, E.; et al. UNITE: A database providing web-based methods for the molecular identification of ectomycorrhizal fungi. New Phytol. 2005, 166, 1063-1068. [CrossRef]

38. Grangeteau, C.; Gerhards, D.; von Wallbrunn, C.; Alexandre, H.; Rousseaux, S.; Guilloux-Bénatier, M. Persistence of two non-Saccharomyces yeasts (Hanseniaspora and Starmellera) in the cellar. Front. Microbiol. 2016, 7, 268. [CrossRef]

39. Werner, O.; Ros, R.M.; Guerra, J. Direct amplification and $\mathrm{NaOH}$ extraction: Two rapid and simple methods for preparing bryophyte DNA for polymerase chain reaction (PCR). J. Bryol. 2002, 24, 127-131. [CrossRef] 
40. White, T.J.; Bruns, T.D.; Lee, S.B.; Taylor, J.W. Amplification and direct sequencing of fungal ribosomal RNA genes for phylogenetics. In PCR Protocols: A Guide to Methods and Applications; Innis, M.A., Ed.; Academic Press: New York, NY, USA, 1990; pp. 315-322.

41. Esteve-Zarzoso, B.; Belloch, C.; Uruburu, F.; Querol, A. Identification of yeasts by RFLP analysis of the 5.8S rRNA gene and the two ribosomal internal transcribed spacers. Int. J. Syst. Bacteriol. 1999, 49, 329-337. [CrossRef]

42. Legras, J.-L.; Karst, F. Optimisation of interdelta analysis for Saccharomyces cerevisiae strain characterisation. FEMS Microbiol. Lett. 2003, 221, 249-255. [CrossRef]

43. Rodriguez, M.E.; Orozco, H.; Cantoral, J.M.; Matallana, E.; Aranda, A. Acetyltransferase SAS2 and sirtuin SIR2, respectively, control flocculation and biofilm formation in wine yeast. FEMS Yeast Res. 2014, 14, 845-857. [CrossRef]

44. Ocón, E.; Gutiérrez, A.R.; Garijo, P.; López, R.; Santamaría, P. Presence of non-Saccharomyces yeasts in cellar equipment and grape juice during harvest time. Food Microbiol. 2010, 27, 1023-1027. [CrossRef]

45. Ocón, E.; Garijo, P.; Sanz, S.; Olarte, C.; Santamaría, P.; Gutiérrez, A.R. Analysis of airborne yeast in one winery over a period of one year. Food Control 2013, 30, 585-589. [CrossRef]

46. Abdo, H.; Catacchio, C.R.; Ventura, M.; D’Addabbo, P.; Alexandre, H.; Guilloux-Bénatier, M.; Rousseaux, S. The fungal life of a new winery: Establishment of the fungal consortium. Sci. Rep. 2019. (Under Review).

47. Sabate, J.; Cano, J.; Esteve-Zarzoso, B.; Guillamon, J.M. Isolation and identification of yeasts associated with vineyard and winery by RFLP analysis of ribosomal genes and mitochondrial DNA. Microbiol. Res. 2002, 157, 267-274. [CrossRef]

48. Barata, A.; Malfeito-Ferreira, M.; Loureiro, V. The microbial ecology of wine grape berries. Int. J. Food Microbiol. 2012, 153, 243-259. [CrossRef]

49. Mortimer, R.; Polsinelli, M. On the origins of wine yeast. Res. Microbiol. 1999, 150, 199-204. [CrossRef]

50. Valero, E.; Cambon, B.; Schuller, D.; Casal, M.; Dequin, S. Biodiversity of Saccharomyces yeast strains from grape berries of wine-producing areas using starter commercial yeasts. FEMS Yeast Res. 2007, 7, 317-329. [CrossRef]

51. Warth, A.D. Resistance of yeast species to benzoic and sorbic acids and to sulfur dioxide. J. Food Prot. 1985, 48, 564-569. [CrossRef]

52. Henick-Kling, T.; Edinger, W.; Daniel, P.; Monk, P. Selective effects of sulfur dioxide and yeast starter culture addition on indigenous yeast populations and sensory characteristics of wine. J. Appl. Microbiol. 1998, 84, 865-876. [CrossRef]

53. Constantí, M.; Reguant, C.; Poblet, M.; Zamora, F.; Mas, A.; Guillamón, J.M. Molecular analysis of yeast population dynamics: Effect of sulphur dioxide and inoculum on must fermentation. Int. J. Food Microbiol. 1998, 41, 169-175. [CrossRef]

54. Vezinhet, F.; Hallet, J.; Valade, M.; Poulard, A. Ecological survey of wine yeast strains by molecular methods of identification. Am. J. Enol. Vitic. 1992, 43, 83-86.

55. Le Jeune, C.; Erny, C.; Demuyter, C.; Lollier, M. Evolution of the population of Saccharomyces cerevisiae from grape to wine in a spontaneous fermentation. Food Microbiol. 2006, 23, 709-716. [CrossRef] [PubMed]

56. Garijo, P.; Santamaría, P.; López, R.; Sanz, S.; Olarte, C.; Gutiérrez, A.R. The occurrence of fungi, yeasts and bacteria in the air of a Spanish winery during vintage. Int. J. Food Microbiol. 2008, 125, 141-145. [CrossRef] [PubMed]

57. Grangeteau, C.; Gerhards, D.; Rousseaux, S.; von Wallbrunn, C.; Alexandre, H.; Guilloux-Bénatier, M. Diversity of yeast strains of the genus Hanseniaspora in the winery environment: What is their involvement in grape must fermentation? Food Microbiol. 2015, 50, 70-77. [CrossRef] [PubMed]

58. Torija, M.J.; Rozès, N.; Poblet, M.; Guillamón, J.M.; Mas, A. Yeast population dynamics in spontaneous fermentations: Comparison between two different wine-producing areas over a period of three years. Antonie Leeuwenhoek 2001, 79, 345-352. [CrossRef] [PubMed]

59. Schuller, D.; Alves, H.; Dequin, S.; Casal, M. Ecological survey of Saccharomyces cerevisiae strains from vineyards in the Vinho Verde region of Portugal. FEMS Microbiol. Ecol. 2005, 51, 167-177. [CrossRef] [PubMed]

60. Nunes, J.M.; Bizerra, F.C.; Ferreira, R.C.; Colombo, A.L. Molecular identification, antifungal susceptibility profile, and biofilm formation of clinical and environmental Rhodotorula species isolates. Antimicrob. Agents Chemother. 2013, 57, 382-389. [CrossRef] 
61. Pu, L.; Jingfan, F.; Kai, C.; Chao-An, L.; Yunjiang, C. Phenylethanol promotes adhesion and biofilm formation of the antagonistic yeast Kloeckera apiculata for the control of blue mold on citrus. FEMS Yeast Res. 2014, 14, 536-546. [CrossRef]

62. Weerasekera, M.M.; Wijesinghe, G.K.; Jayarathna, T.A.; Gunasekara, C.P.; Fernando, N.; Kottegoda, N.; Samaranayake, L.P. Culture media profoundly affect Candida albicans and Candida tropicalis growth, adhesion and biofilm development. Mem. Do Inst. Oswaldo Cruz 2016, 111, 697-702. [CrossRef]

63. Kuthan, M.; Devaux, F.; Janderová, B.; Slaninová, I.; Jacq, C.; Palková, Z. Domestication of wild Saccharomyces cerevisiae is accompanied by changes in gene expression and colony morphology. Mol. Microbiol. 2003, 47, 745-754. [CrossRef]

64. Arroyo-López, F.N.; Salvadó, Z.; Tronchoni, J.; Guillamon, J.M.; Barno, E.; Quérol, A. Susceptibility and resistance to ethanol in Saccharomyces strains isolated from wild and fermentative environments. Yeast 2010, 27, 1005-1015. [CrossRef] [PubMed]

65. Nadai, C.; Treu, L.; Campanaro, S.; Giacomini, A.; Corich, V. Different mechanisms of resistance modulate sulfite tolerance in wine yeasts. Appl. Microbiol. Biotechnol. 2016, 100, 797-813. [CrossRef] [PubMed]

(C) 2020 by the authors. Licensee MDPI, Basel, Switzerland. This article is an open access article distributed under the terms and conditions of the Creative Commons Attribution (CC BY) license (http://creativecommons.org/licenses/by/4.0/). 